\title{
Health literacy and health related lifestyle among nursing students
}

Kompetencje zdrowotne i zdrowy tryb życia wśród studentów pielęgniarstwa

Tamara Štemberger Kolnikํ, Dejan Hozjan², Katarina Babnik ${ }^{1}$

'University of Primorska, Faculty of Health Sciences

2University of Primorska, Faculty of Education

CORRESPONDING AUTHOR/AUTOR DO KORESPONDENCJI:

Tamara Štemberger Kolnik

Faculty of Health Sciences

University of Primorska

Polje 42, 6310 Izola, Slovenia

e-mail: tamara.kolnik@fvz.upr.si

STRESZCZENIE

Słowa kluczowe:

ABSTRACT

Key words:

\section{KOMPETENCJE ZDROWOTNE I ZDROWY TRYB ZYYCIA WSROOD STUDENTÓW PIELEGNIARSTWA}

Wprowadzenie. Studenci pielęgniarstwa stanowią istotną populację osób do zgłębiania wiedzy dotyczącej kompetencji zdrowotnych oraz zachowań prozdrowotnych. Z jednej strony jest to grupa młodych dorosłych rozpoczynających samodzielną troskę o wlasne zdrowie, a z drugiej, uczą się oni by być profesjonalistami, którzy będą przekazywać wsparcie i wiedzę ludziom poprzez zmianę ich stylu życia dążąc do zachowania ich zdrowia lub walki z chorobą. W związku z tym, niniejsze badanie ukierunkowane jest na zgłębianie tematyki kompetencji zdrowotnych oraz zachowań prozdrowotnych wśród studentów pielęgniarstwa.

Materiał i metoda. Badaniem kompetencji zdrowotnych oraz zachowań prozdrowotnych objęto grupę 337 studentów programów związanych z z opieką zdrowotną w Słowenii. Wykorzystano dwa narzędzia badawcze do zgłębienia kompetencji zdrowotnych studentów (Kwestionariusz 0ceny Kompetencji Zdrowotnych i Skróconą ocenę kompetencji i opieki zdrowotnej - Newest Vital Sign) oraz skalę mierzącą zachowania prowozdrowotne.

Wyniki. Analiza czynnikowa wyodrębniła trzy wymiary kompetencji zdrowotnych: rozumienie zdrowia lub choroby, rozumienie instrukcji otrzymywanych od służby zdrowia i orientacja w zakresie systemu zdrowia. Zmienne odnoszące się do kompetencji zdrowotnych i zachowań prozdrowotnych są ściśle powiązane.

Dyskusja i wnioski. Edukacja studentów pielęgniarstwa powinna kłaść nacisk na tematy kompetencji zdrowotnych oraz ich własnej ochrony zdrowia. Powinna także wspierać i zachęcać studentów do prowadzenia zdrowego trybu życia, jako, że powinni oni stanowić przykład tego co wpajają pacjentom.

opieka zdrowotna, zachowania prozdrowotne, kompetencje zdrowotne

\section{WEALTH LIERACY AND HEALTH RELATED LIFESTYLE AMONG NURSING STUDENIS}

Introduction. Nursing students are an important population for the study of health literacy and health-related behaviours. On one hand, they are a population of young adults, that is starting to independently take care of their own health and on the other hand, they are becoming professionals who will provide support and pass knowledge to people making changes in their lifestyle in order to preserve their health or to manage a disease. The focus of this research is therefore oriented towards the study of health literacy and behavior related to health in the population of nursing students.

Material and methods. We have studied health literacy and behaviour related to health on a sample of 337 students from the health care study programmes in Slovenia. We utilised two instruments to measure students' health literacy (Health Literacy Screening Questions and Quick assessment of literacy and primary care - Newest vital sign) and a scale to measure health-related behaviors. Results. Factor analysis identified three dimensions of health literacy: the understanding of health or disease, the understanding of the instructions received in the health system and the orientation within the health system. Variables related to health literacy and health-related behaviors are closely connected.

Discussion and conclusion. The education of nursing students should put emphasis on the topics of health literacy and their own health care. It should also support and encourage students to maintain healthy living habits, as they themselves should set an example of what they teach the patients.

health care, behavior related to health, health literacy 


\section{INTRODUCTION}

When defining health literacy, Marks [1] emphasizes the importance of understanding and utilisation of data obtained in the health care system, and the ability to identify the usefulness and credibility of the information obtained. The level of health literacy depends on various factors, such as socio-economic status, gender, ethnic affiliation and ethnicity, the severity of the disease, previous experiences related to health, occupation and other [2-6]. General literacy and the level of education are also among the important factors of health literacy [1,7-9]. Sørensen et al [10] defines health literacy as an individual's knowledge, motivation and ability to: (I) access health information, (II) understand this information, (III) critically review and apply health information. Health information, used in this way, contributes to maintaining or improving the quality of life in the health area in all stages of life. The connection between the concept of health literacy and the health of the individual was already emphasized in the first definition of health literacy, that was formulated by the World Health Organisation: »Health literacy represents the cognitive and social skills which determine the motivation and ability of individuals to gain access to, understand and use information in ways which promote and maintain good health.« $[11,12]$. Health literacy is based on the concept of functional literacy [13], which represents an essential tool for the success of individuals in society. The construct of health literacy contains the elements of the concept of general literacy and other skills related to health, which are needed to cope with the complex healthcare system and health-oriented behaviour [14]. In modern society, health is regarded primarily as an individual, and to lesser extent as a collective entity, which directs to thinking, that the care for the preservation of health is associated primarily with the perception and experience of an individual's own health or disease [15]. Van Servellen [6] and Baker [4] indicate that medically literate people are more self-effective in the area of health and have more positive behaviour regarding health. Long and Gambling [16] note that people with a lower level of health literacy are less effective in chronic disease self-management. Deeks et al. [17] emphasize that the age is associated with health-related behaviours, because every life stage has its own specifics. Adolescents are an important group for the study of health literacy and behaviour related to health. They will become independent users of the health system and responsible for the independent care of their own health very soon. Ghaddar et al. [8] found that nearly half of the sample of adolescents included in the study has limited health literacy (11\%) or possibly limited health literacy (37\%). Health literacy is significantly higher in the adolescent population who attended school programs for health professionals [8]. A low level of health literacy among pupils and students was also found in Italy, where they confirmed a link between health literacy with the level of education and field of study [18]. The students of health related study courses show greater attention to health and seek more information related to health [19].
The purpose of this article is to examine health literacy and behaviour related to health in the population of nursing students. We have chosen such population because they will, as future health professionals, be an important factor impacting the level of health literacy and consequently health related behaviour of the population with which they will be in contact at work.

\section{MATERIALS AND METHODS}

A quantitative research paradigm was used for the execution of the survey. For data collection we used previously developed and validated questionnaires.

\section{Description of the instrument}

The questionnaire included mainly closed-ended questions. Variables, that indicate individual characteristics were the following: demographic characteristics (gender, age, education) and health-related variables (blood sugar, cholesterol level and body mass index). For measuring Health Literacy we utilised the $»$ Health Literacy Screening Questions «[20] that includes 16 items that respondents evaluate on a five-point scale of frequency, where 1 meant »never « and 5 meant »always «. The Chew et al.s [20] questionnaire was first tested in Slovenia in 2012 [21]. For the purpose of this research we added to the original items [20] seven items that reassemble specific characteristics of the Slovenian health care system. The questionnaire (number of items $=24$ ) shows adequate internal consistency $(\alpha=.87)$. Behaviour associated with health was measured with items developed by Sarafino [22] $(\alpha=.58)$. The questionnaire includes 7 original items [22] and 3 items added by the authors for the Slovenian sample. Respondents evaluated items on a five-point scale of frequency, where 1 meant »never « and 5 meant »always«. We also used the standardised screening instrument to measure health literacy »Quick assessment of literacy and primary care Newest vital sign (NVS)«, from the authors Weiss et al. [23] to identify the level of health literacy of students.

\section{Sample}

The research was conducted on a sample of nursing students. The questionnaires were distributed among 5 Slovenian higher education institutions that perform nursing care study programmes. We distributed 410 questionnaires among students of the undergraduate and postgraduate study program of nursing. To carry out the research we have previously obtained the consent of each faculty or higher education institution. We received 337 questionnaires. In accordance with the fact that nursing is predominantly a female profession, the sample consisted of 268 women and 58 men. Most participants were between the 19 and 24 years old. The respondents stated that their previously completed education is, in 296 cases secondary, in other 24 cases college or higher level of education than secondary. Respondents most commonly stated that they visit the doctor less than once a year. On a scale from 1 to 10 , where 1 is the worst and 10 is the best score, the surveyed students mainly evaluate their state of health with an assessment of eight or higher (76.1\%) (very good health). 


\section{Description of the conducted research and data processing}

Before the study we have obtained the consent of the National Medical Ethics Committee and each higher education institution where the research took place. In every higher education institution included in the study there was a designated person to distribute the questionnaires among students and to send them back to the researchers when completed. We conducted factor analysis with varimax rotation for the variable health literacy.

We calculated the Pearson correlation coefficient between the overall variables »health literacy « (ZP), dimensions of health literacy (HL1, HL2, HL3), overall variable »behaviour related to health « (B) and »self-perceived health status« $(\mathrm{H})$.

\section{RESULTS}

Table 1 represents the items of the instrument that we utilised to measure health literacy [20], the arithmetic mean and standard deviation of the responses and factors extracted by factor analysis. The factor analysis (principal component, varimax rotation) has extracted 3 factors with eigenvalue greater than 1 , which together explain the $43.14 \%$ of variation in the responses of the participants. The last seven items shown in the table 1, represent items that were added to the original questionnaire developed by authors Chew et al. [20], and are adapted to the Slovenian health care system and culture.

The assessment of health literacy with the NVS [23] showed that in the sample of nursing students, 37.3 percent of respondents had adequate health literacy, 46.1 percent were under the category of possibly limited health literacy and 16.7 percent suggest high likelihood (50\% or more) of limited health literacy.

Tab. 1. Descriptive statistics and factor analysis of the health literacy questionnaire.

\begin{tabular}{|c|c|c|c|c|c|}
\hline & \multicolumn{3}{|c|}{ Component } & \multirow[b]{2}{*}{ Mean } & \multirow[b]{2}{*}{$\begin{array}{c}\text { Std. } \\
\text { Deviation }\end{array}$} \\
\hline & HL1 & HL2 & HL3 & & \\
\hline How often are medical forms written in a way that is easy to read and understand? & & & .784 & 3.61 & .737 \\
\hline How often are appointment slips written in a way that is easy to read and understand? & & & .741 & 3.65 & .753 \\
\hline How often are medication labels written in a way that is easy to read and understand? & & & .692 & 3.92 & .826 \\
\hline How often are patient educational materials written in a way that is easy to read and understand? & & & .594 & 3.70 & .811 \\
\hline How often are medical forms difficult to understand and fill out? & & .751 & & 3.21 & .858 \\
\hline How often are appointment slips difficult to understand? & & .722 & & 3.24 & .836 \\
\hline How often are hospital or clinic signs difficult to understand? & & .644 & & 3.08 & .909 \\
\hline How often do you have problems completing medical forms because of difficulty in understanding the instructions? & & .635 & & 3.73 & .838 \\
\hline How often are directions on medication bottles difficult to understand? & & 613 & & 3.43 & .877 \\
\hline $\begin{array}{l}\text { How often do you have problems getting to your clinic appointments at the right time because of difficulty in } \\
\text { understanding written instructions? }\end{array}$ & & .560 & & 4.03 & .914 \\
\hline $\begin{array}{l}\text { How often do you have difficulty in understanding written information your health care provider (like a doctor, nurse, } \\
\text { nurse practitioner) gives you? }\end{array}$ & & .453 & & 3.35 & .888 \\
\hline I know my medical condition well and I know when I have to see a doctor. & .639 & & & 4.22 & .841 \\
\hline I am accompanied by a family member, a friend, a guardian or someone else, to my medical appointments. & .590 & & & 3.84 & 1.086 \\
\hline I know and understand all the test results and the information that I receive regarding my health. & .555 & & & 3.69 & .84 \\
\hline $\begin{array}{l}\text { How often do you have someone (like a family member, a friend, a hospital/clinic worker, or a caregiver) to help you read } \\
\text { hospital materials? }\end{array}$ & .551 & & & 3.88 & .972 \\
\hline $\begin{array}{l}\text { I leave to others decisions regarding the administration of therapy and maintenance of health (diet, physical activity, } \\
\text { etc.). }\end{array}$ & .544 & & & 4.18 & 1.048 \\
\hline How often are you able to say if the health-related information given by the media is reliable? & .528 & & & 3.58 & 0.895 \\
\hline How confident do you feel you are able to follow the instructions on the label of a medication bottle? & .521 & & & 3.72 & .883 \\
\hline The instructions and the invitations to participate in preventive programs are easy for me to understand. & .509 & & & 4.02 & 0.9 \\
\hline How confident do you feel filling out medical forms by yourself? & .499 & & & 3.65 & .929 \\
\hline $\begin{array}{l}\text { How often are you unsure on how to take your medication(s) correctly because of problems with understanding written } \\
\text { instructions on the bottle label? }\end{array}$ & .467 & & & 3.91 & .885 \\
\hline $\begin{array}{l}\text { How often do you have problems with learning about your medical condition because of difficulty understanding } \\
\text { written information? }\end{array}$ & .453 & & & 3.73 & .849 \\
\hline On my medical visits in health institutions, I find the instructions given by the health professionals, incomprehensible. & .339 & & & 3.51 & .955 \\
\hline Cronbach alpha factoral dimensions & 0.81 & 0.79 & 0.75 & & \\
\hline The arithmetic mean of dimensions & 3.82 & 3.43 & 3.74 & & \\
\hline The standard deviation of dimension & 0.53 & 0.58 & 0.58 & & \\
\hline
\end{tabular}


In the table 2 the items of the »behaviour related to health " variable are presented (B). As shown, the surveyed students rarely or moderately drink alcoholic beverages (3.87), often eat breakfast every day (3.57), and have normal weight (3.76). Sometimes they sleep 7 to 8 hours (3.44), eat between meals (3.43), manage stress (3.30) and have their meals prepared in accordance with the instructions of healthy diet (3.13). They rarely attend activities for the prevention of chronic non-communicable diseases (2.56) and they seldom rest at home when sick (2.46). We found that $56 \%$ of the respondents have normal body weight with the value of body mass index between 19.9 and 24.9. A small percentage of the respondents were obese (7.3\%), since their body mass indexes was above 30 , and $17.1 \%$ of the respondents were malnourished. Malnutrition is mostly present in women aged under 24 . Blood sugar levels within the normal range were evaluated in $94.9 \%$ of the respondents, the rest of the sample showed minimal increase in blood sugar. Elevated levels of total cholesterol in blood were evaluated in $37.1 \%$ of the respondents.

Tab. 2. Health behaviour.

\begin{tabular}{|l|c|c|}
\hline & Mean & $\begin{array}{c}\text { Std. } \\
\text { Deviation }\end{array}$ \\
\hline I drink alcohol rarely or moderately & 3.87 & .919 \\
\hline I' have appropriate weight or near & 3.76 & 1.316 \\
\hline I eat breakfast almost every day & 3.57 & 1.366 \\
\hline I regularly get vigorous physical activity & 3.47 & 1.103 \\
\hline I sleep 7 or 8 hours a day & 3.44 & 1.109 \\
\hline I eat between meals & 3.43 & 1.081 \\
\hline I manage stress successfully in everyday life & 3.30 & .846 \\
\hline $\begin{array}{l}\text { My meals are prepared according to the guidelines } \\
\text { of healthy diet }\end{array}$ & 3.13 & .958 \\
\hline I attend prevention programs (SVIT, ZORA, CINDI) & 2.56 & 1.491 \\
\hline When I get sick I stay at home & 2.46 & 1.023 \\
\hline
\end{tabular}

The correlation between variables »understanding of disease ( HL1), »orientation « (HL2), »understanding instructions" (HL3), »health literacy«, »health-related behaviours" (B) and »self-assessment of health status» $(\mathrm{H})$ show the close link between all the variables. The respondents that indicate a higher level of health literacy (HL) indicate better »orientation « in the health system (HL2), more appropriate "understanding of the disease (HL1) and "understanding instructions « related to health (HL3). They also assessed their health status $(\mathrm{H})$ better and they show increased frequency of positive behaviours associated with health (B) (Table 3).

\section{DISCUSSION}

Health literate population, health professions and politicians who make the policy should also create a health literate society [12]. Health literate society is closely related to urbanization and scientific discovery including advances in medical and communication technologies. These are the elements that affect the individual's perception of health and well-being [24], which we must consider when talking about health literacy and behaviour linked to health. With the factor analysis, we have identified three dimensions of health literacy. Based on the arguments we reasonably defined them into groups that represent: I. Ability to understand the factors of a healthy lifestyle and symptoms of disease; II. Ability to understand the instructions and the importance of adherence of the patient; III. Effective orientation and functioning within the health system. The extracted factors explained 43.14 percent of the variability of health literacy in the population of nursing students. Kanj and Mitic [12] argue that in order to create a health literate population, we must join forces in the policy of the countries within health and education system, to create a health literate society. Health literacy measured with the screening instrument NVS [23] showed that $37.3 \%$ respondents have adequate health literacy. Shu-Ching et al. [19] confirmed in a study that there is a connection between health education, health literacy and health-related behaviours. The students included in the sample will be the future supporters of patients changing their living habits. As the designers of health education programs they should also be role models for patients who are changing their life habits for the better. The results of our study show, that the behaviour associated with health in the studied population was average. Most of the students only sometimes track their diet, sleep 7 to 8 hours, exercise regularly and manage stressful situations. However, they often reach out for alcoholic drinks. They rarely attend preventive activities related to health and they rarely stay at home to recover from a disease. The correlation coefficients between the studied variables confirm the close link between general health literacy, all three dimensions of health literacy, health-related behaviour and self-assessed health status of the respondents. The data suggest that health literacy is an important factor for the interpretation of behaviour related to health and the perception of the health status.

Tab. 3. Pearson Correlation with collected variables.

\begin{tabular}{|l|c|c|c|c|c|c|}
\hline & $\begin{array}{c}\text { Health } \\
\text { literacy(HL) }\end{array}$ & $\begin{array}{c}\text { Health } \\
\text { behaviour(B) }\end{array}$ & $\begin{array}{c}\text { Self-perceived } \\
\text { health status (H) }\end{array}$ & $\begin{array}{c}\text { Understanding } \\
\text { instructions (HL2) }\end{array}$ & $\begin{array}{c}\text { Understanding of } \\
\text { the disease (HL1) }\end{array}$ & $\begin{array}{c}\text { Orientation } \\
\text { (HL3) }\end{array}$ \\
\hline Health literacy (HL) & 1 & & & & & \\
\hline Health behaviour (B) & $.219^{* *}$ & 1 & & & & \\
\hline Self-perceived health status (H) & $.174^{* *}$ & $.294^{* *}$ & 1 & & & \\
\hline Understanding of instructions (HL2) & $.676^{* *}$ & $.112^{*}$ & .074 & 1 & & \\
\hline Understanding of the disease (HL1) & $.750^{* *}$ & $.334^{* *}$ & $.239^{* *}$ & $.423^{* *}$ & 1 & \\
\hline Orientation (HL3) & $.855^{* *}$ & $.158^{* *}$ & $.120^{*}$ & $.357^{* *}$ & $.500^{* *}$ & 1 \\
\hline
\end{tabular}

** $p=<0.01 \quad{ }^{*} p=<0.05$ 


\section{CONCLUSION}

Curriculum for medical care program is designed based on the orientation of the various organizations responsible for the regulated profession competences. The competencies of nurses are aimed at strengthening and preserving health, early detection and treatment of illness or injury, as well as at support for a peaceful death in all age groups of patients. Students of nursing, therefore, acquire expert knowledge that can demonstrate high health literacy, but they do not administer this knowledge in their life nor use it for self-care. One of the restrictions of the research is the fact that we only considered some of the factors that affect the concepts of health literacy and health-related behaviour. In the future researches it would make sense to find and take into account all the factors. Both of these concepts are highly complex and closely linked to the individual's personality and social factors. Nevertheless, we can highlight the importance of empowering the population with information related to health during training and throughout all the stages of life, so that we can adapt the content to the needs of the population according to the age group and specific needs of the certain vulnerable groups. To carry out these activities, it is essential to think about the good foundation of knowledge for all the students of nursing.

\section{REFERENCES}

1. Marks R. Health Literacy and School-Based Health Education. New York: York College, The City University of New York and Teachers College, Columbia University; 2012.

2. LeeS-YD, Arozullah AM, Cho YI. Health literacy, social support, and health: a research agenda. Soc Sci Med. 2004; 58(7): 1309-1321.

3. Speros C. Health literacy: concept analysis. J Adv Nurs. 2005; 50(6): 633-640.

4. Baker DW. The meaning and the measure of health literacy. J Gen Intern Med. 2006; 21(8): 878-883.

5. Paasche-Orlow MK, Wolf MS. The causal pathways linking health literacy to health outcomes. Am J Health Behav. 2007; 31(1): S19-26.

6. Van Servellen G. Communication skills for the health care professional; concepts, practice and evidence, 2nd ed. Jones and Barlett, Sudbury (Ma.). 2009, p. 203.

7. Manganello JA. Health literacy and adolescents: a framework and agenda for future research. Health Education Research. 2008; 23(5): 840-847.

8. Ghaddar SF, Valerio MA, Garcia CM, Hansen L. Adolescent Health Literacy: The Importance of Credible Sources for Online Health Information. J Sch Health. 2012; 82(1): 28-36.

9. Zarcadoolas C, Pleasant A, Greer DS. Understanding health literacy: an expanded model. Health Promot Int. 2005; 20(2): 195-203.

10. Sørensen K, Van den Broucke S, Fullam J, et al. Health literacy and public health: a systematic review and integration of definitions and models. Am J Trop Med Publ Health. 2012; 12(80): 6-13.

11. Nutbeam D. Health promotion glossary. Health Promot Int. 1998; 13(4): 349-364.

12. Kanj M, Mitic W. Health Literacy and Health Promotion. Nairobi, Kenya: World Health Organization. 2009. Available at: http://www.who.int/healthpromotion/ conferences/7gchp/Track 1_Inner.pdf.

13. Nutbeam D. Defining and measuring health literacy: what can we learn from literacy studies?. Int J Publ Health. 2009; 54 (5): 303-305.

14. Liechty J. Health literacy: critical opportunities for social work leadership in health care and research. Health Soc Work. 2011; 36(2): 99-107.

15. Kamin T. Zdravje na barikadah. Dileme promocije zdravja. Ljubljana: Univerza v Ljubljani. Fakulteta za družbene vede. 2006.

16. Long AF, Gambling T. Enhancing health literacy and behavioural change within a tele-care education and support intervention for people with type 2 diabetes. Blackwell Publishing Ltd Health Expectations. 2011;15(3): 267-282.

17. Deeks A, Lombard C, Michelmore J, Teede $H$. The effects of gender and age on health related behaviors. BMC Public Health. 2009; 9(213): 1-8. doi:10.1186/1471-2458-9-213.
18. Grappasonni I, Petrelli F, Klusoňová $H$, Kračmarová L. Level of understanding of medical terms among italian students. Ceska Slov Farm. 2016; 65(6): 216-220.

19. Shu-Ching Y, Yi-Fang L, Chia-Hsun C. The Associations Among Individual Factors, eHealth Literacy, and Health-Promoting Lifestyles Among College Students. J Med Internet Res. 2017;19(1): e15. D0I: 10.2196/jmir.5964.

20. Chew LD, Bradley KA, Boyko EJ. Brief questions to identify patients with inadequate health literacy. Family Medicine. 2007; 36(8): 588-594.

21. Štemberger Kolnik T, Babnik K. Development of the health literacy instrument for Slovenian population : results of the pilot study. V: Železnik D, (ur.), Kaučič BM, (ur.), Železnik U. (ur.). Innovation in step with the time - best practice examples: proceedings of lectures with peer rewiev. Slovenj Gradec: University College of Health Sciences; 2012, p. 248-255.

22. Sarafino EP. Health Psychology. Biopsychosocial Interactions. Fifth.ed. Hoboken (NJ): J. Wiley \& Sons, cop; 2006, p. 140.

23. Weiss $B D$, Mays $M Z$, Martz $W$, et al. Quick assessment of literacy in primary care: the newest vital sign. Ann Fam Med. 2005; 3(6): 514-522.

24. Zarcadoolas C, Pleasant FA, Greers D. Advancing Health Literacy. A frame work for Understanding and Action. San Francisco: John Wiley\&Sons; 2006, p. 1-6.

Manuscript received: 03.02.2017

Manuscript accepted: 14.06.2017

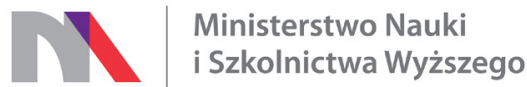

„Konsultacje z zagranicznymi naukowcami i wprowadzenie dwujęzycznych (j. polski/angielski) treści do czasopisma Pielęgniarstwo XXI wieku" finansowane w ramach umowy 547/P-DUN/2016 ze środków Ministra Nauki i Szkolnictwa Wyższego przeznaczonych na działalność upowszechniającą naukę. 